\title{
Climate change adaptation, flood risks and policy coherence in integrated water resources management in England
}

\author{
David Benson $^{1} \cdot$ Irene Lorenzoni $^{2}$
}

Received: 6 September 2015 / Accepted: 12 March 2016/Published online: 22 April 2016

(C) The Author(s) 2016. This article is published with open access at Springerlink.com

\begin{abstract}
Integrated water resources management (IWRM) assumes coherence between cognate aspects of water governance at the river basin scale, for example water quality, energy production and agriculture objectives. But critics argue that IWRM is often less 'integrated' in practice, raising concerns over inter-sectoral coherence between implementing institutions. One increasingly significant aspect of IWRM is adaptation to climate changerelated risks, including threats from flooding, which are particularly salient in England. Although multiple institutional mechanisms exist for flood risk management (FRM), their coherence remains a critical question for national adaptation. This paper therefore (1) maps the multi-level institutional frameworks determining both IWRM and FRM in England; (2) examines their interaction via various inter-institutional coordinating mechanisms; and (3) assesses the degree of coherence. The analysis suggests that cognate EU strategic objectives for flood risk assessment demonstrate relatively high vertical and horizontal coherence with river basin planning. However, there is less coherence with flood risk requirements for land-use planning and national flood protection objectives. Overall, this complex governance arrangement actually demonstrates
\end{abstract}

David Benson

d.i.benson@exeter.ac.uk

Irene Lorenzoni

i.lorenzoni@uea.ac.uk

1 Environment and Sustainability Institute and Department of Politics, University of Exeter, Penryn, Cornwall TR10 9FE, UK

2 School of Environmental Sciences, Tyndall Centre for Climate Change Research, and the Science, Society and Sustainability (3S) Group, University of East Anglia, Norwich Research Park, Norwich, Norfolk NR4 7TJ, UK de-coherence over time due to ongoing institutional fragmentation. Recommendations for increasing IWRM coherence in England or re-coherence based on greater spatial planning and coordination of water-use and landuse strategies are proposed.

Keywords Integrated water resources management (IWRM) - Flood risk · Institutional fragmentation · Climate change $\cdot$ Adaptation $\cdot$ River basin management planning

\section{Introduction}

Integrated water resources management (IWRM) has acquired paradigmatic status as a key governance approach for the sustainable development of water resources globally (Gain et al. 2013; Rouillard et al. 2014; Benson et al. 2015). Although forms of regional-scale integrated water management date back decades, if not centuries (Molle 2009), in the 1990s the IWRM approach emerged in national policy discourses becoming widely advocated by international organisations such as the European Union and United Nations, and global development organisations. While conceptions differ, several underlying principles are inherent to IWRM in terms of institutional framing, scales of management interaction, public participation, economic valuation of resources and, critically, the effective 'integration' or coherence between cognate policy aspects of water governance at the river basin level-for example, related higher-level demands for water quality, climate adaptation, energy production and agriculture (GWP 2010; Gain et al. 2013). Supporters of IWRM maintain that coherence is essential to effective management due to the interrelated nature of these environmental components, with examples drawn from different countries (e.g. Smith 
et al. 2015). But while questions have been consistently raised over just how 'integrated' IWRM actually is (see Rouillard et al. 2014), the degree to which (in)coherence is evident remains underexplored in the environmental governance literature. Such incoherence is visible in both developed and developing countries (ibid.), potentially providing a significant research agenda for mutual learning and 'lesson-drawing' (Benson and Jordan 2011). This paper therefore examines and assesses the coherence between IWRM, flood risk management (FRM) and landuse planning in England by analysing the institutional coordinating mechanisms that they interact with.

In England, the degree to which integrated water management, in the form of the EU Water Framework Directive (WFD), actually provides coherence with a 'nexus' of cognate policy sectors through river basin planning, particularly agriculture, remains questionable (Fritsch and Benson 2013; Benson et al. 2015). Indeed, one area of potential incoherence is the degree to which WFD objectives are coordinated with parallel demands for climate change adaptation. The Directive already mandates adaptation in the management of water resources, primarily with regard to water quality and abstraction, but an increasingly important aspect in the context of climate change in Europe is flood risk management. The EU Floods Directive 2007, which compels Member States to assess flood risks and integrate them with river basin planning, is one policy driver. Moreover, in England, where climate projections indicate increased flood risks from sea-level rise and more severe storm events (Defra 2012), several national policy initiatives have been adopted in recent years (Lorenzoni et al. 2016). A critical question for IWRM and national climate adaptation in England therefore is the extent to which river basin planning successfully coheres with these policy requirements.

Policy coherence, as opposed to parallel strategic-level governance terms such as policy coordination and 'mainstreaming', remains somewhat underexplored, 'with little research undertaken on the concept, what it means and how it can be assessed' (Nilsson et al. 2012: 396). According to May et al. (2006: 382), 'coherence implies that various policies go together because they share a set of ideas or objectives'. But as we explain, this view of coherence raises questions over how such a concept can be measured and the intervening factors shaping it in practice. One aspect that we focus on in this paper is institutions and the degree of fragmentation between them (see May et al. $2005,2006)$ as an intervening factor in understanding the coherence between IWRM and climate change adaptation policy in the form of flood risk management. An institutional perspective, rather than the focus on policy making typical of coordination or mainstreaming studies, allows greater examination of how policies function or cohere together in practice.

This paper therefore reviews the existing literature on policy coherence to develop an analytical framework. Four main institutional indicators are employed, namely objectives, instruments, implementation and outputs (based on the examination of relevant literature, as outlined in the sections below). These are utilised to examine policy coherence between the WFD and climate adaptation in England, from an institutional perspective, also drawing upon an historical context to current flood risk management and its key institutional characteristics. In terms of environmental governance, England remains distinct from other UK national contexts such as Scotland and provides a good empirical 'test bed' to examine coherence, given its long history of regional scale, integrated forms of water management (Cook 2016; Benson et al. 2013). The analysis shows a complex institutional architecture of regulations, strategies, plans and coordinating mechanisms at multiple levels, including the local. In the final section of this paper, their degree of coherence is assessed and discussed. Although coastal matters are mentioned throughout this paper, as they are covered by IWRM and FRM in England, they are not considered in detail.

\section{Defining and assessing policy coherence}

Policy coherence is a contested concept, with multiple interpretations evident in the governance literature on not only its meaning but also, importantly, its measurement. Thomas (2012: 458), for example, notes how even within the narrow confines of EU foreign policy studies, there is considerable disagreement 'on how to define and measure the concept'. As discussed above, for May et al. (2006: 382), policies should, normatively, cohere where they contain related objectives and ideas. This basic definition reflects Rhodes' (1997: 222) argument that coherence involves the production of 'logically and consistently related policies'. As incoherence can lead to 'implementation gaps' (Mazmanian and Sabatier 1983), normative demands for greater coordination between policy actors to ensure more consistent implementation have come to underpin normative notions of 'network' or 'joined-up' governance (Jordan and Schout 2006; Bevir 2009). A bewildering variety of strategic mechanisms, tools and techniques has consequently been introduced for higherlevel coordination, 'mainstreaming' or integration of parallel objectives within policy formulation, particularly in sustainable development governance, including international policy regimes (OECD 2002; Jordan and Lenschow 2010; Jordan et al. 2015). But problematically, coherent policies need to integrate common ideological precepts or 
objectives throughout their life cycles (following May et al.'s 2006 perspective), indicating that 'coherence' should include a much broader consideration of post-decisional implementation and impacts in practice (see Nilsson et al. 2012). In this sense, coherence should then also entail vertical and horizontal policy interaction between multiple institutional levels throughout these interlinked stages (Nilsson et al. 2012). Hence, Veláquez Gomar et al. (2014: 121) understand coherence in international regimes as a 'complementarity of action (mutual reinforcement)', evident across the policy cycle, in terms of process, outputs and outcomes, at international and national scales. In their view, 'coherent governance' should provide holistic linkage between these elements (ibid.). Yet, while it remains relatively straightforward to measure consistency between higher-level policy ideas or objectives, simply by examining (mis)matches between them in policy outputs, the broader definition of multi-level coherence raises practical questions over empirical measurement of mutual reinforcement throughout the cycle at different levels.

Several approaches to measuring coherence are evident in the governance literature, but they tend to map on to the conventional policy cycle. For public policy analysts, policy processes can be conceptualised as an adaptive cycle involving agenda-setting, formulation, adoption, implementation, evaluation and succession (e.g. Dunn 2004; Hill 2013). Some scholars more narrowly focus on 'upstream' policy coherence in the formulation stage, for example May et al. (2006) who examine correlation between policy issues, interests and the social targeting of measures for a number of US legislative measures. Others have sought to examine post-decisional aspects as well. Veláquez Gomar et al. (2014: 121) examine 'upstream policy processes... the coherency of national policies and implementation arrangements (policy outputs), and the cohesiveness and effectiveness of governance as a whole (outcomes and impacts)'. Nilsson et al. (2012) also employ a multi-level, objectives-led approach to evaluating coherence in EU environmental policy sectors. They also argue that coherence should be examined through the cross-policy interplay between higher-level objectives setting and instrumentation, and its effects on implementation and outputs at the national level. They apply this framework to environmental policy areas to examine their coherence, including the degree of alignment between the WFD and EU renewable energy objectives, suggesting that this type of framework may constitute a potentially ideal approach for studying IWRM.

By combining these arguments, from Nilsson et al. (2012) and May et al. (2006) and the authors' experience of UK water management, we can construct an analytical framework for measuring the degree of (in)coherence between adjacent IWRM policies through their vertical and horizontal institutional interplay (Table 1). Focusing specifically on multi-level institutional fragmentation (May et al. 2006) through time and space allows a sharper empirical focus than that provided by the Nilsson et al.'s framework. Rule-based and organisational institutions are common empirical foci in environmental governance research, particularly water management (Ostrom 2005; Young 2002). Indeed, various scholars have identified institutional design of IWRM as critical to effective 'watershed' or catchment management (Sabatier et al. 2005; Benson et al. 2013). In considering the coherence of strategic-level IWRM policy objectives, we can therefore examine their institutional embedding in policy. Here, drawing on Nilsson et al., coherence could be understood to be high where policy objectives are fully aligned in institutions (i.e. these objectives should not be contradictory or mutually exclusive), whereas incoherence would be associated with non-alignment. IWRM policy instruments (e.g. regulations) would also exhibit compatibility in such institutional frameworks where coherence in their calibration is high. With regard to IWRM implementation, high coherence would equate with coordination between implementing institutions at different scales, including regional (e.g. among designated management plans). Finally, Nilsson et al. (2012) refer to converging outcomes. However, these are often difficult to determine in adaptive water management processes such as river basin planning or watershed management due to the long run nature of planning cycles (see Sabatier et al. 2005; Benson et al. 2014). Therefore, we employ institutional outputs (ibid.) as a proxy for outcomes. For example, IWRM management measures can be considered an output, since these should positively determine outcomes. When assessing coherence in EU water policy, a critical institutional indicator of IWRM coherence would therefore be the degree of vertical and horizontal consistency between higher-level EU objectives, national instrumentation and regional or lower (catchment)-level implementation, and their implications for institutional outputs. Within the WFD, the key institutional output of river basin management would be planderived management measures.

\section{Methods}

The methods employed combined qualitative analysis of key documents with interview data to test the framework. Official documents were collected to initially map the multi-level institutional framework determining IWRM, FRM and land-use planning in England. Main documents employed included a national survey of Local Flood Risk Management Strategies, draft Flood Risk Management 
Table 1 Analytical framework applied in this study, outlining features of IWRM policy (in)coherence in relation to vertical and horizontal aspects, derived from Nilsson et al. (2012), May et al. (2006), Benson et al. (2014). For terminological indications, see text above

\begin{tabular}{|c|c|c|c|}
\hline & High coherence & Partial coherence & Incoherence \\
\hline Objectives & Objectives and targets fully aligned & Objectives and targets partially aligned & No objectives and targets aligned \\
\hline Instruments & Instruments fully compatible & Instruments partially compatible & Instruments incompatible \\
\hline Implementation & $\begin{array}{l}\text { Full coordination in implementing } \\
\text { institutions }\end{array}$ & $\begin{array}{l}\text { Limited coordination in implementing } \\
\text { institutions }\end{array}$ & $\begin{array}{l}\text { No coordination in implementing } \\
\text { institutions }\end{array}$ \\
\hline Outputs & $\begin{array}{l}\text { Full consistency in } \\
\text { planning/management measures }\end{array}$ & $\begin{array}{l}\text { Partial consistency in } \\
\text { planning/management measures }\end{array}$ & $\begin{array}{l}\text { No consistency in } \\
\text { planning/management measures }\end{array}$ \\
\hline
\end{tabular}

Plans, River Basin Management Plans and national flood and planning policy. This national context was chosen as a wider proxy for UK practice, although it should be noted that Scotland, Northern Ireland and Wales have adopted slightly different approaches to water management within overarching EU policy. These documents were then employed, in conjunction with elite interviews with policy actors (Environment Agency, local government), to determine the degree of interaction between four different institutional 'pillars', as discussed below. This interaction was then assessed using the analytical framework (outlined in Table 1) to examine coherence.

\section{River basin and flood risk management in England}

\section{Historical context}

Modern flood risk management in England can be historically related to integrated river basin or catchment-based forms of water management as far back as the early twentieth century (Lorenzoni et al. 2016). Most flood management in Britain before this era had been conducted at local scales by a plethora of private and public actors (Cook 2016). However, between the 1930s and the 1980s, there was a discernible shift from fragmentation and localism towards more holistic, regional approaches that combined flood management with qualitative aspects of water management. Initially, the Land Drainage Act 1930 created drainage districts and catchment boards to provide flood defence and land drainage in certain areas (Cook 2016). These bodies were followed by the establishment of Internal Drainage Boards (IDBs), while catchment boards were replaced by regional River Boards in 1952. Further integration occurred in 1963, with the concentration of River Boards into 27 regional River Authorities which were given responsibility for most water tasks. In 1973, ten Regional Water Authorities (RWAs) were then established to manage major aspects of water management, including flood defences, at river basin scales. During the late 1970s and early 1980s, flood defence became dominated by large central government-funded land drainage schemes, with flood management mainly conducted in respect of farming and landowning interests (see Penning-Rowsell et al. 1986).

Institutional fragmentation of this relatively integrated approach started in the late 1980s. Ideological shifts in central government under the Thatcher administration meant that expenditure on land drainage was reduced, with resources shifted towards urban and coastal flood defences. Regional Water Authorities in England and Wales became privatised water and sewage service providers, and they lost regulatory functions to the National Rivers Authority (NRA). More significant governance changes occurred in 1995 with the creation of the national Environment Agency (EA). This organisation was given widespread regulatory powers along with supervisory responsibilities for main flood defences, both on land and along the coast. Regional Flood Defence Committees (RDFCs) were formed by the EA to coordinate operations across the country (Lorenzoni et al. 2016). Comprised of EA representatives and local authorities, the Committees had executive powers over flood risk management and maintenance activities of the EA (ibid.). While grant-inaid funds were provided by central government to support this work, RDFCs could also impose local levies to support flood defence projects not meeting national funding priorities. In addition, they could delegate decisions to Local Flood Drainage Committees, comprised mainly of local council appointees. Locally elected IDBs still continued to operate, playing an important role in flood risk management through their control over water tables. Local authorities also possessed flood defence powers to maintain smaller watercourses and the right to enter private lands to conduct essential drainage work. Therefore, by the late 1990s and early 2000s, an institutionally fragmented architecture of flood risk management was evolving, based on central EA control of major flood defences, local authority powers and non-governmental actor responsibilities. 
At this point, government policy partly shifted from flood defence provision to a more pre-emptive, risk-based management role based on spatial (land use) planning (Porter and Demeritt 2012). As Penning-Rowsell and Handmer (1988) show, flood management in England has been characterised by an uneasy tension between local government land-use planning discretion, within the context of national planning policy guidance, and the need for flood defence of properties. National government circulars, in 1947, 1962 and 1969, had progressively sought to encourage greater cooperation between the two objectives, particularly in preventing development on floodplains (ibid.). Water authorities at this time, however, were only given an advisory role meaning that flood risks were sometimes overlooked in planning decisions. The UK Government, in response, introduced Planning Policy Guidance Note (PPGN) 25 in 2000 (now Planning Policy Statement or PPS 25), which created a statutory consultation role for the Environment Agency in such developments. Local planning authorities then were required to produce risk-based assessments of development plans and decisions. The EA could 'call-in' decisions where it suspected that its recommendations were not followed. As a planning decision-support tool, the EA produced flood risk maps for local authorities to employ showing areas most at risk of inundation. Catchment Flood Management Plans, covering river flood risks in priority catchments, were also developed by the EA to provide long-term strategic management objectives. Shoreline Management Plans (SMPs) that provide assessments of coastal erosion and flood risks were produced in parallel via consultation between the EA, marine district authorities and other relevant bodies.

The underlying ideology of national flood risk management began to shift again in the mid-2000s. Traditional hard engineering responses were modified to allow for greater sustainable development predicated on 'making space for water' (Johnson and Priest 2008). Based on an enhanced decision-making role for non-state actors, cofunding and more holistic approaches to flood control planning, this approach came under significant scrutiny in 2007 (discussed further below). 'Europeanization' of UK water policy also continued during this period with the adoption of the European Union (EU) Floods Directive 2007 (Lorenzoni et al. 2016). The Directive requires Member States to harmonise flood risk management approaches by conducting Preliminary Flood Risk Assessments, producing maps showing flood risks and producing national plans for managing flood risks. In response, the EA has since produced flood maps on a national basis showing areas potentially at risk from river, sea or reservoir flooding.
In England, these governance structures came under severe pressure during the floods of 2000-2001 and then in 2007 when widespread flooding was particularly destructive in the north-east and central England in June, and in southern areas during July. Responding to criticisms of its flood risk management policy, the Government initiated a review conducted by Sir Michael Pitt. His report (known as the Pitt Review) was damning of existing flood management and made several recommendations for change (Cabinet Office 2008). Most notably, he identified the need for adequate resourcing of flood resilience measures and pre-planned emergency funding for exceptional events. Recommendations were also made for increasing flood risk information to the public via maps (EA 2013), along with an enhanced role for local authorities and the public in managing flood defences. Pitt suggested that these measures should be coordinated through a national action plan to provide oversight.

The UK Government ministry responsible for flood matters, Defra ${ }^{1}$ (the Department for Environment, Food and Rural Affairs), responded to the Pitt Review by supporting all of the 92 recommendations (Defra 2008). In particular, it pledged new responsibilities for the EA in the strategic management of flood risks, more and better modelling of flood risk and greater cooperation between the national-level and local authorities 'to support them in taking on a local leadership role, including responsibility for local flood risk management including surface water risk' (ibid.: 5). Additional funds were pledged by Defra for helping local authorities perform these roles.

The government adopted the Flood and Water Management Act 2010 to implement its response to the Pitt Review. Among the main changes contained in the Act were providing lead powers to upper-tier local authorities (county council, unitary authorities) for local flood risk management, flood investments and cooperation with the EA and other stakeholders such as district councils, IDBs and water companies. As a result of this commitment, there has been further institutional fragmentation of floods governance. The Environment Agency still retained overall responsibility for coordinating flood risk management nationally. This system was supported by a new institutional governance structure for flood and coastal erosion risk management (FCERM). Subsequent national policy became framed by the National Flood and Coastal Erosion Risk Management Strategy (2011), with Defra designated as the lead government ministry and the EA the implementing agent. As a result, the EA is now directly responsible for managing around $70 \%$ of flood defences in

\footnotetext{
${ }^{1}$ Defra is the lead Government department for national flood management policy, which determines the actions of the main implementing agents such as the Environment Agency.
} 
England: primarily concerning flood risks from major rivers, coastal inundation and reservoirs (Bennett 2014: 8). ${ }^{2}$ The remaining 'third-party assets' are overseen by IBDs, local authorities and private actors (ibid.). Critical coordinating mechanisms between these different actors are the Regional Flood and Coastal Committees (RFCCs) that replaced the RDFCs in 2011 (Lorenzoni et al. 2016). These Committees are comprised of Lead Local Flood Authorities (LLFAs-county councils and unitary authorities) and expert appointees, who work with the EA in determining flood defence spending for specific projects on a regional scale (ibid.).

\section{Mapping the current governance landscape}

Given this long historical development and ongoing institutional fragmentation, the current relationship between river basin management and flood risk management in England is highly complex. In mapping this complexity, we can refer to four main institutional 'pillars' or policy strands: the Water Framework Directive; the Floods Directive; national FCERM policy; and land-use planning (Fig. 1). These institutional mechanisms are linked by coordinating mechanisms, discussed in more detail below.

Firstly, the Water Framework Directive is the main mechanism for implementing IWRM in the European Union. By the mid-1990s, the perceived inability of some 'first-generation' water policies, introduced by the EEC in the 1970s, to address non-point source pollution problems led to demands for more holistic approaches (Benson and Jordan 2008). As a result, the European Commission developed proposals for the Water Framework Directive, adopted in 2000. Based upon IWRM principles (see Gain et al. 2013), the Directive mandates the creation of River Basin Districts (RBDs) across the EU, some spanning national borders. Within each river basin, Member States are compelled to undertake river basin management planning. Designated implementing authorities must develop a plan, in conjunction with public participation, comprised of a Programme of Measures (POMs) aimed at achieving the 'good ecological status' of surface (and 'good chemical status' of ground) waters within each river basin, including coastal waters. The second phase of planning finished in 2015 , with subsequent future plan revisions adopted on a six-year cycle thereafter. Implementation in England has now met the requirements of the Directive, although to date

\footnotetext{
2 The Environment Agency in England operates on an area structure since April 2014 (totalling 16 geographical areas). The Environment Agency Wales operated until April 2013 as a Welsh Governmentsponsored body; it then merged with Countryside Council for Wales and Forestry Commission Wales to become a single environmental body, Natural Resources Wales.
}

the impact on water quality has been limited (Benson et al. 2014).

While aimed primarily at improving water quality, the Directive also integrates climate adaptation. Member States were recommended to include adaptation measures in the first planning phase. Some measures-mainly related to water quality and abstraction-were therefore included in many national planning approaches prior to 2009, but research in EU states suggests that these have been limited in practice (Brouwer et al. 2013). Indeed, in England, all the RBD plans produced by the Environment Agency make reference to adaptation measures; yet, these almost exclusively seek to support water quality objectives and manage abstraction activities under predicted future conditions of climate change. Integration of planning with other climaterelated flood risks is, however, anticipated under the Floods Directive (2007/60/EC).

Secondly, adopted in 2007 in response to devastating floods in central Europe, the Floods Directive aims 'to reduce and manage the risks that floods pose to human health, the environment, cultural heritage and economic activity' (European Commission 2015). In meeting this aim, Member States were compelled, by 2011, to conduct preliminary flood risk assessments to determine which river basins and coastal zones are vulnerable. These areas, once identified, then were required to be incorporated into flood risk maps by 2013, which would inform flood risk management plans by 2015. Implementation of the Floods Directive is designed to coordinate with the Water Framework Directive in terms of the production of flood risk management plans and river basin management plans, planning timescales and the participation of public actors in this process.

Requirements of the Floods Directive are implemented by the UK national Flood Risk Regulations 2009 (Statutory Instrument 2009/3042). Under the Regulations, Risk Management Authorities (RMAs), comprised of multiple actors, work together collaboratively to manage flood risk. Lead Local Flood Authorities (LLFAs) (unitary or county councils) prepared preliminary assessment reports of flooding risks in their jurisdictions which were reviewed by the Environment Agency (EA). After the EA's review, a preliminary assessment map was produced for each river basin based on information provided by the EA and other sources. A preliminary assessment report was then produced by the LLFA. The Environment Agency then identified flood risk areas within each river basin district, with LLFAs obliged to state whether they were significant. Preliminary assessment maps and reports were then published for each river basin district in 2011. Both LLFAs and the Environment Agency then reviewed these documents, prior to preparing flood hazard maps and flood risk maps, which must be consistent with river basin management 
Fig. 1 Institutional context of IWRM/FCERM in England

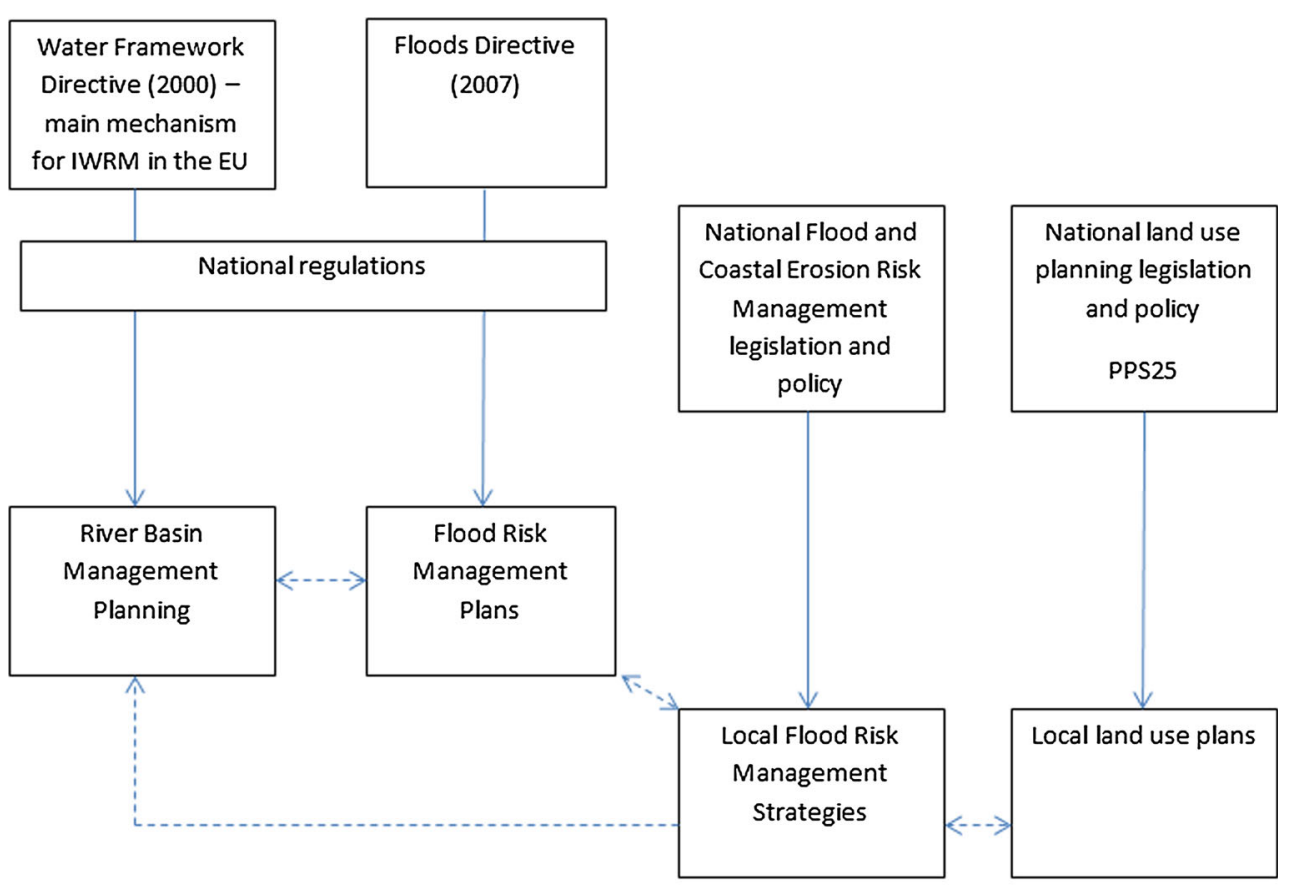

Institutional mechanisms plans. Published by the EA in 2013, the maps were then reviewed by both actors. Finally, there is a requirement on both parties to prepare flood risk management plans (FRMP). The EA must produce FRMPs for river basin districts, while LLFAs are legally obliged to produce plans for flood risk areas to support the FRMP. Plans must coincide with river basin management plans, the multiannual planning cycle established by the Water Framework Directive and national FCERM objectives. The EA produced draft FRMPs (required under the Flood Risk Regulations 2009) and draft updated river basin management plans (required under the WFD) which were published for coordinated consultation in 2014 , partly to provide stakeholders with opportunities to consider options for more effective water management (EA 2015). In England, these plans were published in late 2015, with subsequent reviews to be completed by 2021 and at six yearly cycles thereafter.

Thirdly, the UK government has, since 2011, introduced additional requirements for FCERM that map on to preexisting institutional structures while providing new roles for agencies and local authorities. As discussed above, Defra still assumes overall policy control, with the Environment Agency retaining strategic operational responsibility for implementing policy. However, the Environment Agency must collaborate with other actors to manage flood risks from 'third-party assets' with Lead Local Flood Authorities, Internal Drainage Boards and water companies, each of which has specific management roles
(Table 2). A particularly important role is assigned under the 2010 Act to LLFAs who are responsible for localised flood risks from surface water, groundwater, smaller watercourses and highway run-off but also for protecting parts of the coastline. Management is supported by grantin-aid funding from central government, supplemented by local authority match spending and local levies (Lorenzoni et al. 2016). Coordination between central and local government is achieved via the Regional Flood and Coastal Committees (RFCCs) (ibid.) and national policy requirements. The latter obligations require LLFAs to produce a Local Flood Risk Management Strategy (LFRMS) covering flooding from localised sources that must be consistent with the National Flood and Coastal Erosion Risk Management Strategy, FRMPs and preliminary flood risk assessments. Communities and other Risk Management Authorities (RMAs) must be consulted in the development of LFRMS. Other governance mechanisms used in LFRMS development are catchment flood management plans (CMPs), Shoreline Management Plans and Surface Water Management Plans. First developed in the 2000s, CMPs have been completed for 68 sub-regional catchments across England and Wales, setting long-term (i.e. 50-100 year) objectives for inland flood risk management and helping to shape investment decision-making within river basin districts. Complementary Shoreline Management Plans are developed with local authorities and the EA to cover coastline in England, based on individual 'sediment cells' 
Table 2 Statutory flood risk management responsibilities for specific water resources assumed by different actors in England

\begin{tabular}{ll}
\hline Actor & $\begin{array}{l}\text { Water resources responsibilities } \\
\text { in flood risk management }\end{array}$ \\
\hline Environment Agency & Main rivers \\
& Coastal waters \\
& Reservoirs \\
& Surface water \\
Lead Local Flood Authorities & Groundwater \\
& Ordinary watercourses \\
& Highway run-off \\
Water companies & Sewers and drains \\
Internal Drainage Boards (IDBs) & Internal drainage districts \\
Transport agencies (Network Rail, & Railway culverts \\
British Waterways, Highways & Canals \\
Agency) & Motorway drainage \\
Landowners/riparian owners & Individual watercourses \\
\hline
\end{tabular}

linked to distinct coastal processes. Surface Water Management Plans, meanwhile, are prepared by local authorities for specific high-risk locations, in conjunction with local stakeholders.

Finally, flood risk requirements for local land-use planning are outlined in broader national planning policy. General planning requirements were reformed by the National Planning Policy Framework (NPPF) (Department for Communities and Local Government 2012), which aims to avoid and manage flood risks through local planning authority responsibilities for producing development plans and determining planning applications. Under Section 10, entitled 'Meeting the challenge of climate change, flooding and coastal change', local planners are obliged to:

'adopt proactive strategies to mitigate and adapt to climate change, taking full account of flood risk, coastal change and water supply and demand considerations.' (ibid.: 22)

The NPPF determines that development should be either directed away from high-risk areas or made safe from flood risks when deemed necessary, with Surface Water Management Plans the key mechanisms for this purpose. Under the implementing instrument (PPS 25), local plans must therefore be subject to Strategic Flood Risk Assessments, using advice from the EA and LLFAs. Where risks are identified, specific management policies must be included in the plan. In addition, so-called Sequential ${ }^{3}$ and

\footnotetext{
3 The Sequential Test aims to steer development to locations where there is a low probability of flooding. An Exception Test can be used to grant planning permission where developments show that they have increased resilience to flooding and reduced residual risk to properties and owners.
}

Exception Tests should be applied to new developments to reduce risks, while the long-term sustainability of schemes under conditions of future climate change should be considered. Planners are also required to consider the viability of new developments within Coastal Change Management Areas, which cover areas deemed at risk from coastal erosion and inundation. Other national-level flood risk policy obligations on local planning stem from Building Regulations, which were amended after the Pitt Review. Part $\mathrm{H}$ of the Building Regulations now requires planning permission for the paving of front gardens with impermeable material. Approval for sustainable urban drainage systems (SUDS) that avoid connecting sewerage systems with surface water run-off is also required for construction with drainage implications. The Localism Act 2011 may also prove significant for future flood risk management via local planning. Communities will be encouraged to input into local flood risk management strategies that will inform neighbourhood planning. In response, organisations such as Serve On, who provide disaster relief for flooding, and community flood action groups are now providing more 'bottom-up' solutions (see Cook and Inman (2012) for a discussion on the growth of this sector).

\section{Applying the framework: coherence, incoherence, de-coherence and re-coherence}

In applying the evaluative framework (outlined in Table 1 earlier), different degrees of coherence are visible between these institutional pillars: objectives; instruments; implementation; outputs. There is evident coherence between the Water Framework Directive and Floods Directive 'pillars', certainly in terms of higher-level objectives, instrument calibration and implementing institutions (plans). Both have policy objectives established at the EU level, with the Floods Directive deliberately designed to integrate with the WFD. Indeed, while the Floods Directive points out that 'reducing the risks of floods is not one the principal objectives of... [the Water Framework Directive]' it 'will contribute to mitigating the effects of floods' (Official Journal of the European Communities 2007: 27). So while the WFD is specifically aimed at achieving 'good' ecological and chemical status of waters, and the Floods Directive with reducing risks from flooding, these qualitative and quantitative aspects of water management are intended to be integrated together through the common obligation for river basin management planning. In this respect, there is coherence again at the national level, in terms of the national regulations (instruments) which transpose both directives (i.e. The Water Environment (Water Framework Directive) Regulations 2003 and Flood Risk Regulations 2009). At the implementation level, in 
England, the requirements for flood risk management plans (institutions) at the time of writing are in the process of completion, with consultation occurring on FRMPs to ensure consistency with river basin management planning. Outputs, in the form of management plan measures, should in theory ensure a degree of coherence at the river basin scale. Government guidance to RMAs on preparing plans therefore requires inter-institutional coordination through the inclusion of 'information about... the implementation of measures under the FRMP and river basin management plans' (GOV.UK 2014). An examination of draft FRMPs and their attendant strategic environmental assessments shows that regional plans and constituent catchment plans do consider WFD objectives. But, critically, few flood risk management plan measures are identified as contributing to them, or their contribution is only broadly specified. For example, in the South West catchment draft FRMP, only nine of the 502 individual flood risk 'actions' detailed across eleven catchments mention their contribution to WFD objectives; the majority providing no specific details or stating generally that they would work with 'natural processes' to ensure water management objectives.

There appears to be some coherence between nationallevel FCERM and the WFD, but problems are evident. Most notably, objectives and instruments are set at different institutional levels, with national FCERM approaches contained in the Flood and Water Management Act 2010 and national policy. Lead Local Flood Authorities are obliged to specify how their LFRMS 'contributes to the achievement of wider environmental objectives' (Section 9 (4) (i)), although the WFD is not explicitly mentioned. Local Government Authority (LGA) implementing guidance does however state that Strategies should consider the WFD in their development and that they 'should be assessed for WFD compliance to ensure that local measures to reduce flood risk comply with the WFD' and support its objectives (LGA 2011: 20). To an extent, there is coherence with implementing institutions, with a majority of LFRMS sampled for this research ${ }^{4}$ considering WFD objectives in Strategy development, although not necessarily providing specific links to river basin management plans. Most LLFAs also employed their Strategic Environmental Assessments as inter-institutional coordinating mechanisms to examine coherence with Strategy measures ex post, but some assessments just note that WFD plans were considered. It was therefore difficult to show that outputs, in the form of LFRMS management measures, provided consistency with WFD plan measures. That said, LFRMS were generally supported by preliminary flood risk

\footnotetext{
${ }^{4}$ A sample of 42 Local Flood Risk Management Strategies from across England were analysed for their consistency with the WFD.
}

assessments and hence were indirectly integrated with Flood Risk Management Planning.

There also appears to be only limited coherence with the WFD and land-use planning, with significant mismatches in policy objectives, instruments, implementation and outputs. Broader objectives for land-use planning are contained in national legislation: specific objectives for flood risk management are set out in the NPPF, which provides general obligations on local planning authorities for ensuring development addresses flood risks but does not directly cite coherence with EU objectives. The main policy instrument, in this case PPS 25, also provides only marginal linkage with the Water Framework Directive regulations. PPS 25 states that regional spatial strategies (RSS) policies should be consistent with river basin management planning. However, implementation at the local level is through the production of local spatial strategies and local plans, neither of which map directly on to regional-scale river basin management planning. Strategic flood risk assessments of local plans do, to an extent, provide a broad inter-institutional coordinating mechanism with FRMP. Also, local plan policy development must consider other relevant plan objectives, including the WFD. But mismatches exist in terms of actual outputs, in this case planning decisions. Mitigating measures for individual developments such as SUDS can contribute to both flood reduction and water quality objectives; yet, this does not constitute a fully integrated approach.

This analysis consequently shows both patterns of coherence and incoherence through time and institutional space. Some aspects of flood risk management policy, in the form of the Floods Directive implementation, do manifestly cohere with the river basin management approach in terms of higherlevel objectives, instruments and plans, although actual planning measures in the form of FRMPs are yet to be fully aligned. Other aspects of policy, such as national FCERM and land-use planning, appear less coherent due to evident scale mismatches in objectives, instruments, implementation and outputs. Despite the existence of inter-institutional coordinating mechanisms (e.g. strategic environmental assessments) and coordinating bodies (primarily the Environment Agency, LLFAs, RFCCs), the approach to IWRM appears less than fully 'integrated' in practice. Yet, this pattern of partial coherence has arguably increased through time due to institutional fragmentation, i.e. de-coherence. Most tasks for water management, including flood management and maintaining water quality, were concentrated in the Regional Water Authorities in the 1970s. Consequently, England actually had more integrated forms of water resources management 40 years ago, with the succession of policy changes in the intervening years inducing multiple plans and a patchwork of responsibilities. Policy analysts would recognise this process as an example of path dependency, whereby '[o]nce a particular path gets established... self-reinforcing 
processes make reversals very difficult' (Pierson 2004: 10). Whether this institutionally fragmentary evolution is leading to more effective management of flood risks is a matter of conjecture-recent flood events in northern England in December 2015 may infer that it is not.

To an extent, this pattern could be anticipated, given the long history of institutional fragmentation that has occurred since the 1970s. The UK Government National Audit Office (2011) hence questioned the compatibility of different planning elements of FCERM, introduced under the National Strategy, stating that:

'We have identified 19 individual policy and planning documents that sit behind these plans. [...] There is considerable overlap in these plans and local decision-making is hampered by having to cross-refer to different national content' (p.28)

While the NAO (2011) argues that Local Flood Risk Management Strategies should 'eliminate the need to refer to the underlying plans' (ibid.), the impression given from our analysis is that they have not necessarily led to greater clarity.

This observation raises questions over how coherence could be pursued in the future, to promote the greater integration of IWRM in England, i.e. re-coherence. One approach could be to base all aspects of water and land management at the river basin scale, via integrated spatial planning. Here, objectives for water quality and flood management could be reconciled through a rationalisation of plans, with river basin and catchment-scale planning being the most obvious mechanism for alignment. There is some scope to further integrate national FCERM with river basin planning via LFRMS, although it would require the greater participation of Lead Local Flood Authorities in this process, given their responsibilities for localised risk management. The Regional Flood and Coastal Committees (RFCCs) could provide an important coordinating mechanism between these authorities and regional planning in the future. However, it is perhaps more problematic in this context to entirely integrate local land-use planning, which often occurs at different scales and under parallel but often competing national policy objectives. Other actors such as IDBs and water companies also have different management objectives, the former concerned with managing flood risk and land drainage together, the latter with ensuring sewerage and water supply.

\section{Conclusions}

Integrated water resources management aims at coherence between different aspects of water management at the regional, river basin scale. Yet, evidence from IWRM approaches globally suggests that it is less coherent in practice. By examining policy requirements in England for river basin management planning under the WFD and other policy 'pillars' for flood risk management, there are indeed different degrees of coherence with policy objectives. Alignment with the requirements for flood risk assessment and mapping under the Floods Directive is relatively high, although actual measures are seemingly yet to be coordinated fully. This situation could be anticipated given that objectives and targets, set at the European level, are designed to be compatible at the regional scale. Yet, given the complexity of flood risk management in England, with parallel national policy objectives for FCERM and landuse planning, other policy 'pillars' exhibit at best partial coherence, at worst incoherence. Local Flood Risk Management Strategies could provide better fit with regional planning, but mechanisms for achieving coherence are not yet fully developed. Land-use planning requirements for managing flood risks show similar degrees of incoherence. One aspect not examined in this paper is the effectiveness of policy outcomes; hence, further research could reflect on whether incoherence is adversely impacting floods governance.

This observation hints at the prospects for 'lessondrawing' (Benson and Jordan 2011) on policy responses for England from other countries worldwide-if coherence is considered a normative aim. While an obvious recommendation for re-coherence would be that greater alignment of national FCERM and land-use policy with IWRM in river basin planning would be optimal, there are nonetheless institutional constraints in England. Spatial planning, whereby all aspects of local water-use and landuse management are considered together at a regional or river basin scale, is a normative ideal. Experiences from countries such as Denmark and the Netherlands could prove instructive (Smith et al. 2015; Cook 2016). But in England, local government land-use planning prerogatives constrain this solution due to mismatches in the scale of objectives. Yet, greater alignment of FCERM is possible if greater 'cross-compliance' between competing objectives can be achieved with river basin planning, thereby fulfilling a central criteria of integrated water resources management. Regional-scale institutional mechanisms such as the RFCCs potentially provide one such coordinating approach, as the institutional landscape in England continues evolving (i.e. new legislation such as the Water Act 2014, changing the structure of the Environment Agency) with provisions relating to flood and coastal erosion risk management.

Acknowledgments The authors acknowledge the support of the Leverhulme Trust (International Network Scheme) and the University of Exeter SSIS Discretionary Fund in researching this article. 
Open Access This article is distributed under the terms of the Creative Commons Attribution 4.0 International License (http://crea tivecommons.org/licenses/by/4.0/), which permits unrestricted use, distribution, and reproduction in any medium, provided you give appropriate credit to the original author(s) and the source, provide a link to the Creative Commons license, and indicate if changes were made.

\section{References}

Bennett O (2014) Flood defence spending in England. Standard note SN/SC/5755. House of Commons Library, London

Benson D, Jordan A (2008) Understanding task allocation in the European Union: exploring the value of federal theory. J Eur Public Policy 15(1):1-20. doi:10.1080/13501760701702215

Benson D, Jordan A (2011) What have we learned from policy transfer research? Dolowitz and Marsh revisited. Pol Stud Rev 9(3):366-378. doi:10.1111/j.1478-9302.2011.00240.x

Benson D, Jordan A, Cook H, Smith L (2013) Collaborative environmental governance: are watershed partnerships swimming or are they sinking? Land Use Policy 30(1):748-757. doi:10.1016/j.landusepol.2012.05.016

Benson D, Fritsch O, Cook H, Schmid M (2014) Evaluating participation in WFD river basin management in England and Wales: processes, communities, outputs, outcomes. Land Use Policy 38:213-222. doi:10.1016/j.landusepol.2013.11.004

Benson D, Gain AK, Rouillard JJ (2015) Water governance in a comparative perspective: from IWRM to a 'nexus' approach? Wat Altern 8(1):756-773

Bevir M (2009) Key concepts in governance. Sage, London

Brouwer S, Rayner T, Huitema D (2013) Mainstreaming climate policy: the case of climate adaptation and the implementation of EU water policy. Environ Plann C 31:134-135. doi:10.1068/ c11134

Cabinet Office (2008) The Pitt review: learning lessons from the 2007 floods. Cabinet Office, London

Cook H (2016) The protection and conservation of water resources: a new British perspective. Wiley, Chichester

Cook H, Inman A (2012) The voluntary sector and conservation for England: achievements, expanding roles and uncertain future. J Environ Manag 112:170-177. doi:10.1016/j.jenvman.2012.07. 013

Defra (2008) The government's response to Sir Michael Pitt's review of the summer 2007 floods. Defra, London

Defra (2012) UK climate change risk assessment 2012. Defra, London

Department for Communities and Local Government (2012) National planning policy framework. DCLG, London

Dunn W (2004) Public policy analysis (3e). Pearson, New Jersey

Environment Agency (EA) (2013) Flood map for planning (from rivers and the sea). Environment Agency, Bristol. http://apps. environment-agency.gov.uk/wiyby/37837.aspx

Environment Agency (EA) (2015) Managing flood and coastal erosion risks in England: 1 April 2014 to 31 March 2015. EA, Bristol

European Commission (2015) Implementing the EU water framework directive $\&$ the floods directive. European Commission, Brussels. Accessed 05/02/2015: http://ec.europa.eu/environment/ water/water-framework/objectives/implementation_en.htm

Fritsch O, Benson D (2013) Integrating the principles of IWRM? River basin planning in England and Wales. Int $\mathrm{J}$ Water Gov 1(3-4):265-284. doi:10.7564/13-IJWG7

Gain AK, Rouillard JJ, Benson D (2013) Can integrated water resources management increase adaptive capacity to climate change adaptation? A critical review. J Water Resource Prot 5(4A):11-20. doi:10.4236/jwarp.2013.54A003

GOV.UK (2014) Guidance: flood risk management plans (FRMPs): how to prepare them. UK Government, London

GWP (Global Water Partnership) (2010) IWRM components. GWP, Stockholm. Accessed online at: http://www.gwp.org/en/TheChallenge/What-is-IWRM/IWRM-Principles/

Hill M (2013) The public policy process. Routledge, London

Johnson C, Priest SJ (2008) Flood risk management in England: a changing landscape of risk responsibility. Int $\mathrm{J}$ Water Res Dev 24(4):513-525. doi:10.1080/07900620801923146

Jordan A, Lenschow A (2010) Environmental policy integration: a state of the art review. Environ Policy Gov 20:147-158. doi:10. 1002/eet.539

Jordan A, Schout A (2006) The coordination of the European Union: exploring the capacities of network governance. Oxford University Press, Oxford

Jordan A, Turnpenny J, Benson D, Rayner T (2015) The tools of policy formulation: an introduction. In: Jordan A, Turnpenny $\mathbf{J}$ (eds) The tools of policy formulation. Edward Elgar, Cheltenham

Local Government Association (LGA) (2011) Framework to assist the development of the local strategy for flood risk management: 'a living document'. LGA, London

Lorenzoni I, Benson D, Cook H (2016) Regional rescaling in adaptation governance: from agency to collaborative control in flood management in England. In: Knieling JJ (ed) Climate adaptation governance in cities and regions: theoretical fundamentals and practical evidence. Wiley, Chichester

May PJ, Jones BD, Beem BE, Neff-Sharum EA, Poague MK (2005) Policy coherence and component-driven policymaking: arctic policy in Canada and the United States. Policy Stud J 33(1):37-63. doi:10.1111/j.1541-0072.2005.00091.x

May PJ, Sapotichne J, Workman S (2006) Policy coherence and policy domains. Policy Stud J 34(3):381-403. doi:10.1111/j. 1541-0072.2006.00178.x

Mazmanian DA, Sabatier PA (1983) Implementation and public policy. Scott, Foresman and Company, Glenview

Molle F (2009) River-basin planning and management: the social life of a concept. Geoforum 40(3):484-494. doi:10.1016/j.geoforum. 2009.03.004

National Audit Office (NAO) (2011) Flood risk management in England. The Stationary Office, London

Nilsson M, Zamparutti T, Petersen JE, Nykvist B, Rudberg P, McGuinn J (2012) Understanding policy coherence: analytical framework and examples of sector-environment policy interactions in the EU. Environ Policy Gov 22(6):395-423. doi:10. 1002/eet.1589

OECD (2002) Improving policy coherence and integration for sustainable development. OECD, Paris

Official Journal of the European Union (2007) Directive 2007/60/EC of the European Parliament and the Council of 23 October 2007 on the assessment of flood risks. Official Journal, Brussels

Ostrom E (2005) Understanding institutional diversity. Princeton University Press, Princeton

Penning-Rowsell EC, Handmer JW (1988) Flood hazard management in Britain: a changing scene. Geograph J 154(2):209-220. doi: $10.2307 / 633847$

Penning-Rowsell EC, Parker DJ, Harding DM (1986) Floods and drainage: British policies for hazard reduction, agricultural improvement and wetland conservation. George Allen and Unwin, London

Pierson P (2004) Politics in time. Princeton University Press, Princeton NJ

Porter J, Demeritt D (2012) Flood risk management, mapping and planning: the institutional politics of decision-support in England. Environ Plann A 44(10):2359-2378. doi:10.1068/a44660 
Rhodes RAW (1997) Shackling the leader? Coherence, capacity and the hollow crown. In: Weller P, Bakvis H, Rhodes RAW (eds) The hollow crown: countervailing trends in core executives. Macmillan Press, London, pp 198-223

Rouillard JJ, Benson D, Gain AK (2014) Evaluating IWRM implementation success: are water policies in Bangladesh enhancing adaptive capacity to climate change impacts? Int J Water Res Dev 30(3):515-527. doi:10.1080/07900627.2014. 910756

Sabatier PA, Focht W, Lubell M, Trachtenburg Z, Vedlitz A, Matlock M (eds) (2005) Swimming upstream: collaborative approaches to watershed management. MIT Press, Cambridge

Smith LS, Benson D, Hiscock K (2015) Groundwater protection programmes in Denmark, Germany and the Netherlands. In:
Smith LS, Porter K, Hiscock K, Porter MJ, Benson D (eds) Catchment and river basin management: integrating science and governance. Earthscan, London

Thomas DC (2012) Still punching below its weight? Coherence and effectiveness in European Union Foreign policy. J Common Mark Stud 50(3):457-474. doi:10.1111/j.1468-5965.2011. 02244.x

Veláquez Gomar JO, Stringer LC, Paavola J (2014) Regime complexes and national policy coherence: experiences in the biodiversity cluster. Global Gov 20:119-145. doi:10.5555/10752846-20.1.119

Young OR (2002) The institutional dimensions of environmental change: fit, interplay, and scale. MIT Press, Cambridge 